\title{
Perbedaan Kadar Leukosit dan Limfosit Paska Pemberian Kombinasi Vitamin B Parenteral pada Pasien Penyakit Ginjal Kronik dengan Hemodialisis
}

\author{
Rizaldy Taslim Pinzon*, Ester Novitasari, Nining Sri Wuryaningsih \\ Fakultas Kedokteran Universitas Kristen Duta Wacana \\ Jl. Dr. Wahidin Sudirohusodo 5-25 Yogyakarta 55224, Indonesia \\ *e-mail: drpinzon17@gmail.com
}

\begin{abstract}
Abstrak
Penyakit ginjal kronik merupakan penyakit dengan fungsi ginjal menurun secara progresif yang ireversibel dengan berbagai macam etiologi. Pasien dengan gangguan penyakit ginjal kronik pada umumnya mengalami keadaan imunosupresi dan rentan terhadap infeksi. Beberapa penyebabnya adalah adanya abnormalitas pada leukosit polimorfonuklear dan limfosit. Hasil beberapa penelitian menunjukkan bahwa pada pasien yang menjalani hemodialisis didapati kadar vitamin larut air yang rendah. Penurunan angka leukosit juga dapat terjadi akibat penurunan neutrofil dan limfosit yang mungkin disebabkan oleh defisiensi vitamin $B_{6}$ dan $B_{12}$ akibat hemodialisis. Penelitian ini bertujuan untuk mengukur perbedaan angka leukosit, persentase limfosit, dan konsentrasi absolut limfosit setelah pemberian vitamin $B_{1}, B_{6}$, dan $B_{12}$ (kombinasi vitamin B) pada pasien dengan penyakit ginjal kronik yang menjalani hemodialisis. Penelitian ini merupakan penelitian dengan metode kuasi eksperimental design, One Group Pretest Posttest, pada 115 pasien yang terpilih. Pasien diberikan vitamin $\mathrm{B}_{1}, \mathrm{~B}_{6}, \mathrm{~B}_{12}$ secara parenteral setiap kali melakukan hemodialisis yaitu dua kali dalam seminggu yang diberikan selama 1 bulan saat hemodialisis. Data yang diambil berupa angka leukosit, persentase limfosit, dan konsentrasi absolut limfosit. Intervensi yang diberikan berupa pemberian vitamin $B_{1}, B_{6}, B_{12}$ secara parenteral kepada pasien. Setelah pengambilan data selanjutnya dilihat angka leukosit, persentase limfosit dan konsentrasi absolut limfosit sebelum dan sesudah diberi intervensi kemudian dilihat bagaimana pengaruh pemberian vitamin $B_{1}, B_{6}, B_{12}$ secara parenteral terhadap angka leukosit, persentase limfosit dan konsentrasi absolut limfosit pada pasien yang menjalani hemodialisis. Dari hasil penelitian didapatkan 115 pasien yang terdiri dari 72 laki-laki (62,6\%) dan 43 perempuan $(37,4 \%)$. Terdapat perbedaan berupa peningkatan rerata angka leukosit secara bermakna pada visit 1-2 dengan $p$-value $=0.033$ setelah pemberian $B_{1}, B_{6}$, dan $B_{12}$. Terjadi perubahan rerata persentase limfosit dan konsentrasi absolut limfosit setelah pemberian vitamin $B_{1}, B_{6}, B_{12}$, namun perubahan yang terjadi tidak bermakna.
\end{abstract}

Kata kunci: penyakit ginjal kronik, defisiensi vitamin $B_{1}, B_{6}, B_{12}$, perubahan kadar leukosit dan limfosit 


\title{
Difference in Levels of Leukocytes and Lymphocytes After Parenteral Vitamin B Combination Administration in Patients with Chronic Kidney Disease Undergoing Hemodialysis
}

\begin{abstract}
Chronic kidney disease is a disease in which kidney function decreases progressively irreversibly with various etiologies. Patients with chronic kidney disease are generally immunosuppressed and susceptible to infection. Some of the causes are abnormalities in polymorphonuclear leukocytes and lymphocytes. The results of several studies indicate that patients undergoing hemodialysis have low levels of water-soluble vitamins. A decrease in the number of leukocytes can also occur due to a decrease in neutrophils and lymphocytes which may be caused by deficiency of vitamins $B_{6}$ and $B_{12}$ due to hemodialysis. This study aims to measure the difference in levels of leukocytes and lymphocytes after parenteral vitamin B combination administration in patients with chronic kidney disease undergoing hemodialysis This research is a quasi-experimental design, One Group Pretest Posttest, on 115 selected patients. Patients were given vitamin $B_{1}, B_{6}, B_{12}$ parenterally every time doing hemodialysis, twice a week given for 1 month during hemodialysis. The data were taken in the form of leukocyte count, patient lymphocyte percentage, and absolute lymphocyte concentration. The intervention of vitamins $B_{1}, B_{6}, B_{12}$ was given parenterally to the patient. After collect the data, the leukocyte counts, lymphocyte percentage and absolute lymphocyte concentration before and after the intervention were seen, then it was seen how the effect of parenteral administration of vitamins $B_{1}, B_{6}, B_{12}$ on the leukocyte count, lymphocyte percentage and absolute lymphocyte concentration in patients undergoing hemodialysis. From the results of the study, there were 115 patients consisted of 72 men $(62.6 \%)$ and 43 women (37.4\%). There was a difference and effect of giving combination vitamin $B$ in the form of a significant change in the mean number of leukocytes at visits 1-2 with $p$-value $=0.033$. There was a change in the mean of lymphocyte percentage and absolute lymphocyte concentration after administering vitamins $B_{1}, B_{6}, B_{12}$, but the changes were not significant.
\end{abstract}

Keywords: chronic kidney disease, deficiency of vitamins B1, B6, B12, changes in levels of leukocytes and lymphocytes

\section{PENDAHULUAN}

Penyakit ginjal kronik merupakan penyakit dengan adanya kerusakan struktural atau fungsional ginjal dan/atau penurunan laju filtrasi glomerulus kurang dari $60 \mathrm{~mL} /$ menit $/ 1,73$ yang berlangsung lebih dari tiga bulan. Penyakit ginjal kronik mengakibatkan penurunan fungsi ginjal yang progresif, dan pada umumnya berakhir dengan gagal ginjal. (Suwitra, 2014). Data dari Global Burden of Disease (GBD) pada tahun 2015 memperkirakan sekitar 1,2 juta orang meninggal karena penyakit ginjal kronik, angka ini menunjukkan terjadinya peningkatan sebesar 32\% sejak tahun 2005. Secara global terdapat 697,5 juta kasus penyakit ginjal kronik pada tahun 2017. 79 dari 195 
negara yang termasuk dalam GBD memiliki lebih dari 1 juta kasus prevalensi penyakit ginjal kronik pada tahun 2017 (Bikbov et al, 2020)

Secara umum pasien dengan gangguan ginjal kronik mengalami keadaan imunosupresi dan rentan terhadap infeksi meskipun seringkali nilai hitung leukosit didapati normal. Beberapa penyebabnya adalah adanya abnormalitas pada leukosit polimorfonuklear dan limfosit. Limfosit merupakan kunci utama dari respon imun adaptif melawan patogen yang berhasil melewati imunitas alami (Abbas et al, 2016).

Hasil beberapa penelitian menunjukkan bahwa pada pasien yang menjalani hemodialisis didapati kadar vitamin larut air yang rendah. Salah satu penyebab utamanya adalah karena hilangnya vitamin larut air yang berlebihan dalam dialisat. Defisiensi vitamin $B_{6}$ menyebabkan atrofi jaringan limfoid, penurunan jumlah limfosit pada jaringan limfe, penurunan produksi antibodi, juga penurunan proliferasi limfosit serta toksisitas sel T (Donati et al, 2002). Selain vitamin $B_{6}$, defisiensi vitamin $B_{12}$ juga menyebabkan penurunan signifikan jumlah sel T sitotoksik dan sel natural killer (NK) yang dapat berpengaruh terhadap angka limfosit (Mikkelsen et al, 2017). Pada defisiensi vitamin $B_{12}$, neutrofil yang merupakan jenis leukosit paling banyak dapat mengalami penurunan, sehingga penurunan leukosit juga dapat terjadi (Wilson et al, 2017).

Dari literatur dan penelitian sebelumnya diduga bahwa pada penderita penyakit ginjal kronik dapat mengalami abnormalitas leukosit dan limfosit. Gangguan pada limfosit dikarenakan beberapa hal yaitu keadaan uremia, pajanan membrana sefalon pada saat hemodialisis, serta defisiensi vitamin $B_{6}$ yang mungkin terjadi apabila tidak dibantu dengan suplemen. Penurunan angka leukosit juga dapat terjadi akibat penurunan neutrofil dan limfosit yang mungkin disebabkan oleh defisiensi vitamin $B_{6}$ dan $B_{12}$ akibat hemodialisis. Maka dari itu peneliti tertarik untuk mengukur perbedaan leukosit dan limfosit setelah pemberian vitamin $B_{1}, B_{6}$, dan $B_{12}$ (kombinasi vitamin B) pada pasien dengan penyakit ginjal kronik yang menjalani hemodialisis, sehingga dapat menjadi pertimbangan di masa depan terkait efektivitas pemberian vitamin B kombinasi sebagai suplementasi rutin pada pasien yang menjalani hemodialisis.

\section{BAHAN DAN METODE}

\section{Desain Penelitian}

Desain penelitian yang digunakan adalah analitik dengan metode quasi 
Perbedaan Kadar Leukosit dan Limfosit Paska Pemberian Kombinasi Vitamin B Parenteral... Rizaldy Taslim Pinzon, Ester Novitasari, Nining Sri Wuryaningsih

eksperimental dengan one group pre and post test design. Penelitian ini dilakukan di Rumah Sakit Bethesda dan Rumah Sakit Panti Rapih Yogyakarta yang dilakukan pada bulan Agustus 2018 hingga Oktober 2018. Penelitian ini menggunakan data laboratorium darah pasien dengan penyakit ginjal kronik yang menjalani hemodialisis baik sebelum maupun sesudah diberikan intervensi. Pasien diberikan intervensi vitamin $B_{1}, B_{6}, B_{12}$ secara parenteral setiap kali melakukan hemodialisis yaitu dua kali hemodialisis dalam seminggu dan diberikan intervensi selama 1 bulan (total 8 kali pemberian).

\section{Subjek Penelitian}

Pengambilan sampel pada penelitian ini menggunakan teknik consecutive sampling dan didapatkan jumlah sampel sebanyak 115 orang sesuai dengan kriteria inklusi dan eksklusi. Setiap subjek diberikan kombinasi vitamin B intravena.

Setiap subjek diberikan kombinasi vitamin B intravena yaitu Neurobion Injeksi 5000 yang terdiri dari $100 \mathrm{mg}$ vitamin $\mathrm{B}_{1}$, $100 \mathrm{mg}$ vitamin $B_{6}$, dan 5000 mcg vitamin $B_{12}$. Vitamin ini disuntikkan secara intravena setelah setiap hemodialisis. Setiap subjek yang memenuhi kriteria diminta untuk menandatangani formulir informed consent.

Kriteria inklusi dalam penelitian ini adalah: pasien dengan penyakit penyakit ginjal kronik yang menjalani hemodialisis di RS Bethesda dan RS Panti Rapih Yogyakarta yang bersedia mengikuti penelitian dan berusia $>18$ tahun. Kriteria eksklusi dalam penelitian ini adalah: pasien dengan imunodefisiensi didapat seperti menderita HIV/AIDS, dan menderita keganasan, pasien yang mengkonsumsi vitamin $B_{1}, B_{6}$, $\mathrm{B}_{12}>3$ minggu. 


\section{Alur Penelitian}

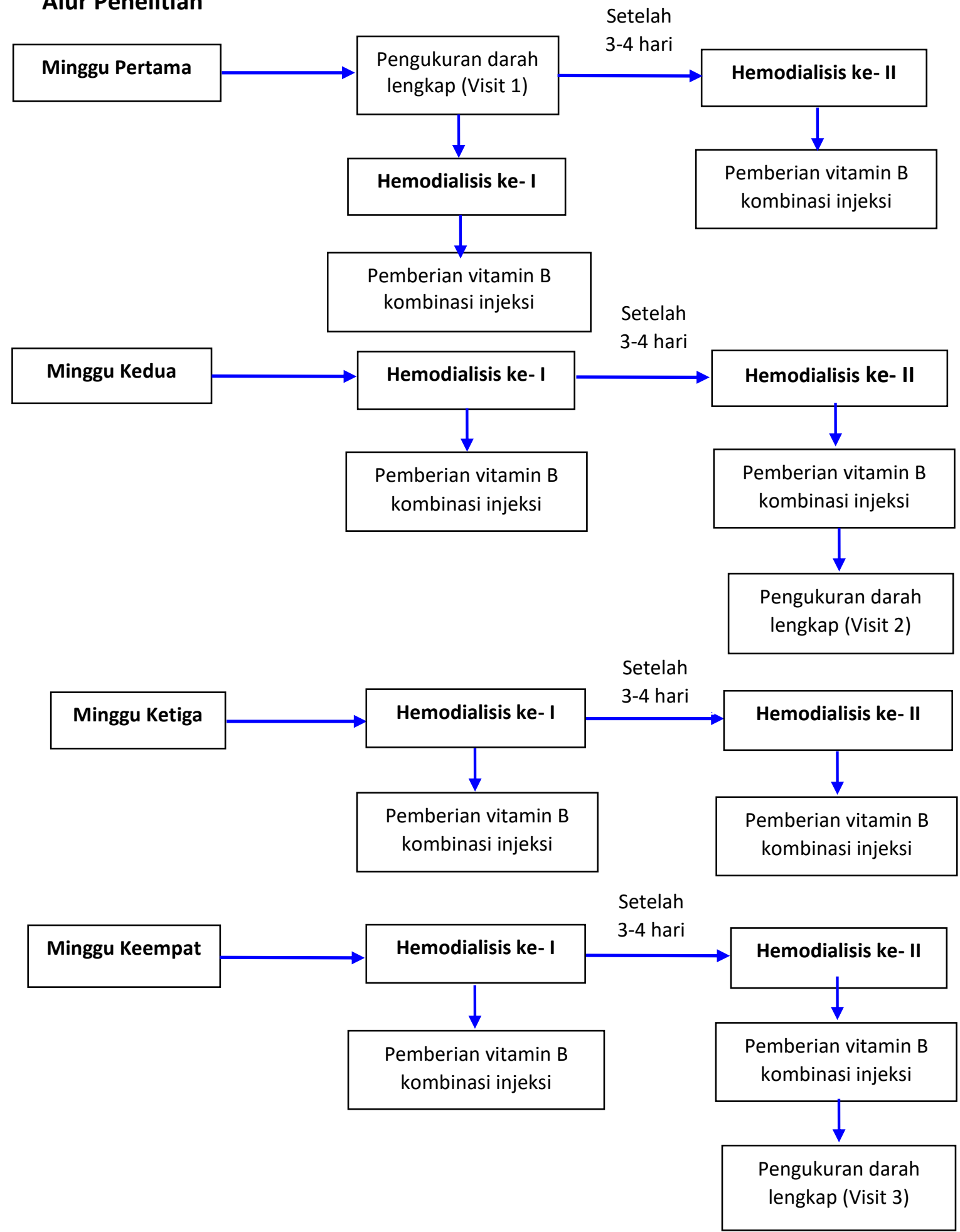


Perbedaan Kadar Leukosit dan Limfosit Paska Pemberian Kombinasi Vitamin B Parenteral... Rizaldy Taslim Pinzon, Ester Novitasari, Nining Sri Wuryaningsih

HASIL

Tabel 1. Karakteristik dasar responden

\begin{tabular}{ccc}
\hline \multicolumn{1}{c}{ Karakteristik Sampel } & $\mathbf{n = 1 1 5}$ & $\mathbf{\%}$ \\
\hline Jenis Kelamin & 72 & 62,6 \\
Pria & 43 & 37,4 \\
Wanita & & \\
Usia (Tahun), Mean \pm SD & 82 & 71,3 \\
$<60$ & 33 & 28,7 \\
$\geq 60$ & & \\
Diabetes Melitus & 39 & 33,9 \\
Ya & 76 & 66,1 \\
Tidak & & \\
Hipertensi & 101 & 87,8 \\
Ya & 14 & 12,2 \\
Tidak & & 27 \\
Penyakit Kardiovaskular & 31 & 73 \\
Ya & 84 & 86,1 \\
Tidak & & 13,9 \\
Anemia & 99 & \\
Ya & 16 & \\
Tidak &
\end{tabular}

Tabel 2. Gambaran angka leukosit, persentase limfosit, nilai konsentrasi absolut limfosit sampel penelitian

\begin{tabular}{cccc}
\hline Variabel & $\begin{array}{c}\text { Visit 1 } \\
\text { (Mean } \pm \text { SD) }\end{array}$ & $\begin{array}{c}\text { Visit 2 } \\
\text { (Mean } \pm \text { SD) }\end{array}$ & $\begin{array}{c}\text { Visit 3 } \\
\text { (Mean } \pm \text { SD) }\end{array}$ \\
\hline Angka leukosit (/mikroLiter) & $7096.00 \pm 2244.15$ & $7495.82 \pm 2369.15$ & $7369.82 \pm$ \\
& & & 2108.68 \\
Persentase limfosit (\%) & $19.06 \pm 7.00$ & $19.13 \pm 7.60$ & $18.48 \pm 7.51$ \\
Nilai konsentrasi absolut limfosit & $1286.33 \pm 462.49$ & $1362.02 \pm 594.45$ & $1317.69 \pm$ \\
$\left(\times 10^{9} /\right.$ L darah) & & & 580.49 \\
\hline
\end{tabular}

Tabel 3. Hasil analisis angka leukosit, persentase limfosit, nilai konsentrasi absolut limfosit sampel penelitian

\begin{tabular}{|c|c|c|c|c|c|c|c|c|c|}
\hline \multirow[t]{2}{*}{ Variabel } & \multicolumn{3}{|c|}{ Visit 1 - Visit 2} & \multicolumn{3}{|c|}{ Visit 2-Visit 3} & \multicolumn{3}{|c|}{ Visit 1 - Visit 3} \\
\hline & $\begin{array}{c}\text { Mean } \\
\pm \\
\text { SD }\end{array}$ & $\begin{array}{c}\text { Mean } \\
\pm \\
\text { SD }\end{array}$ & p-value & $\begin{array}{c}\text { Mean } \\
\pm \\
\text { SD }\end{array}$ & $\begin{array}{c}\text { Mean } \\
\pm \\
\text { SD }\end{array}$ & $\begin{array}{c}\mathrm{p}- \\
\text { value }\end{array}$ & $\begin{array}{c}\text { Mean } \\
\pm \\
\text { SD }\end{array}$ & $\begin{array}{c}\text { Mean } \\
\pm \\
\text { SD }\end{array}$ & p-value \\
\hline $\begin{array}{c}\text { Angka leukosit } \\
\text { (/mikroLiter) }\end{array}$ & $\begin{array}{c}7096.00 \\
\pm \\
2244.15\end{array}$ & $\begin{array}{c}7495.82 \pm \\
2369.15\end{array}$ & 0.033 & $\begin{array}{c}7495.82 \pm \\
2369.15\end{array}$ & $\begin{array}{c}7369.82 \pm \\
2108.68\end{array}$ & 0.332 & $\begin{array}{c}7096.00 \pm \\
2244.15\end{array}$ & $\begin{array}{c}7369.82 \\
\pm \\
2108.68\end{array}$ & 0.068 \\
\hline $\begin{array}{l}\text { Persentase } \\
\text { limfosit (\%) }\end{array}$ & $\begin{array}{c}19.06 \\
\pm \\
7.00\end{array}$ & $\begin{array}{c}19.13 \\
\pm \\
7.60\end{array}$ & 0.531 & $\begin{array}{c}19.13 \\
\pm \\
7.60\end{array}$ & $\begin{array}{c}18.48 \\
\pm \\
7.51\end{array}$ & 0.126 & $\begin{array}{c}19.06 \\
\pm \\
7.00\end{array}$ & $\begin{array}{c}18.48 \\
\pm \\
7.51\end{array}$ & 0.284 \\
\hline $\begin{array}{c}\text { Nilai } \\
\text { konsentrasi } \\
\text { absolut limfosit } \\
\text { (x109 / L darah) }\end{array}$ & $\begin{array}{c}1286.33 \pm \\
462.49\end{array}$ & $\begin{array}{c}1362.02 \pm \\
594.45\end{array}$ & 0.119 & $\begin{array}{c}1362.02 \pm \\
594.45\end{array}$ & $\begin{array}{c}1317.69 \pm \\
580.49\end{array}$ & 0.119 & $\begin{array}{c}1286.33 \pm \\
462.49\end{array}$ & $\begin{array}{c}1317.69 \\
\pm \\
580.49\end{array}$ & 0.530 \\
\hline
\end{tabular}


ISSN 1978-2071 (Print); ISSN 2580-5967 (Online) Jurnal IImiah Kedokteran Wijaya Kusuma 10(1): 27- 44, Maret 2021

Untuk mengetahui hubungan antar variable maka dilakukan uji bivariat menggunakan wilcoxon dikarenakan distribusi data tidak normal dengan menggunakan nilai konfidensi atau taraf kepercayaan sebesar 95\%. Mean atau rerata serta median dari uji ini menunjukkan selisih dari visit 1 ke visit selanjutnya, sedangkan $p$-value dengan nilai $<0,05$ menandakan bahwa perbedaan yang terjadi adalah bermakna.

Hasil uji wilcoxon pada angka leukosit didapati peningkatan rerata dari visit $1 \mathrm{ke}$ visit 2 dengan nilai $p$-value $=0.033$ yang menunjukkan bahwa terjadi perubahan berupa peningkatan rerata yang terjadi secara bermakna $(p<0,05)$. Pada visit 2 dibandingkan visit 3 didapati penurunan rerata dengan nilai $p$-value $=0.332$ yang menandakan perubahan tersebut tidak bermakna. Pada visit 1 dibandingkan visit 3 didapati peningkatan rerata dengan nilai $p$ value $=0.068$ yang menandakan tidak bermakna.

Uji wilcoxon terhadap persentase limfosit menunjukkan adanya peningkatan rerata persentase limfosit dari visit 1 ke visit 2 dengan nilai $p$-value $=0.531$ yang menandakan perubahan tidak bermakna. Penurunan rerata dari visit 2 ke visit 3 dengan nilai $p$-value $=0.126$ yang menandakan terjadi perubahan yang tidak bermakna. Penurunan rerata dari visit 1 ke visit 3 dengan nilai $p$-value $=0.284$ yang menandakan perubahan tidak bermakna, Pada nilai konsentrasi absolut limfosit didapati peningkatan rerata dari visit 1 ke visit 2 dengan nilai $p$-value $=0.119$ yang menandakan perubahan tidak bermakna. Penurunan rerata dari visit 2 ke visit 3 adengan nilai $p$-value $=0.119$ yang menandakan perubahan tidak bermakna. Peningkatan rerata dari visit 1 ke visit 3 dengan nilai $p$-value $=0.530$ yang menandakan perubahan tidak bermakna.

Tabel 4. Gambaran angka leukosit dengan variabel perancu

\begin{tabular}{|c|c|c|c|c|c|c|c|c|c|}
\hline \multicolumn{10}{|c|}{ Angka Leukosit } \\
\hline \multirow[t]{2}{*}{ Variabel } & \multicolumn{3}{|c|}{ Visit 1 - Visit 2} & \multicolumn{3}{|c|}{ Visit 2 - Visit 3} & \multicolumn{3}{|c|}{ Visit 1 - Visit 3} \\
\hline & $\begin{array}{c}\text { Mean } \pm \\
\text { SD }\end{array}$ & $p$-value & Median & $\begin{array}{c}\text { Mean } \pm \\
\text { SD }\end{array}$ & p-value & Median & $\begin{array}{c}\text { Mean } \pm \\
\text { SD }\end{array}$ & $p$ - value & Median \\
\hline \multicolumn{10}{|l|}{ Jenis Kelamin } \\
\hline Pria & $\begin{array}{c}-494.44 \pm \\
1561.73\end{array}$ & 0.559 & -365.00 & $\begin{array}{c}1.11 \\
\pm 1389.36\end{array}$ & 0.124 & -20.00 & $\begin{array}{c}-493.33 \pm \\
1605.61\end{array}$ & 0.121 & -400.00 \\
\hline Wanita & $\begin{array}{c}-241.39 \pm \\
2013.47\end{array}$ & & -270.00 & $\begin{array}{c}335.11 \pm \\
1671.99\end{array}$ & & 380.00 & $\begin{array}{c}93.72 \pm \\
1999.83\end{array}$ & & 30.00 \\
\hline \multicolumn{10}{|l|}{ Usia (Tahun) } \\
\hline$<60$ tahun & $\underset{1671.16}{-491.82} \pm$ & 0.099 & -465.00 & $\begin{array}{l}197.68 \pm \\
1692.33\end{array}$ & 0.323 & 300.00 & $\begin{array}{c}-294.14 \\
\pm 1863.71\end{array}$ & 0.593 & -250.00 \\
\hline$\geq 60$ tahun & $\begin{array}{c}-171.21 \pm \\
1908.29\end{array}$ & & 280.00 & $\begin{array}{c}-52.12 \pm \\
866.39\end{array}$ & & 20.00 & $\begin{array}{c}-223.33 \pm \\
1569.47\end{array}$ & & -120.00 \\
\hline
\end{tabular}


Perbedaan Kadar Leukosit dan Limfosit Paska Pemberian Kombinasi Vitamin B Parenteral...

Rizaldy Taslim Pinzon, Ester Novitasari, Nining Sri Wuryaningsih

\begin{tabular}{|c|c|c|c|c|c|c|c|c|c|}
\hline \multicolumn{10}{|c|}{ Angka Leukosit } \\
\hline \multirow[t]{2}{*}{ Variabel } & \multicolumn{3}{|c|}{ Visit 1 - Visit 2} & \multicolumn{3}{|c|}{ Visit 2 - Visit 3} & \multicolumn{3}{|c|}{ Visit 1 - Visit 3} \\
\hline & $\begin{array}{c}\text { Mean } \pm \\
\text { SD }\end{array}$ & $p$-value & Median & $\begin{array}{c}\text { Mean } \pm \\
\text { SD }\end{array}$ & $p$-value & Median & $\begin{array}{c}\text { Mean } \pm \\
\text { SD }\end{array}$ & $p$ - value & Median \\
\hline \multicolumn{10}{|l|}{ Hipertensi } \\
\hline Ya & $\begin{array}{c}-434.15 \\
1760.51\end{array}$ & 0.309 & -390.00 & $\begin{array}{l}141.48 \pm \\
1558.56\end{array}$ & 0.596 & 220.00 & $\begin{array}{c}-292.67 \pm \\
1826.85\end{array}$ & 0.248 & -300.00 \\
\hline Tidak & $\begin{array}{c}-152.14 \pm \\
1623.07\end{array}$ & & 115.00 & $\begin{array}{c}14.28 \pm \\
1051.02\end{array}$ & & 255.00 & $\begin{array}{c}-137.85 \pm \\
1421.11\end{array}$ & & 480.00 \\
\hline \multicolumn{10}{|c|}{ Diabetes Melitus } \\
\hline Ya & $\begin{array}{c}-206.41 \pm \\
1632.14\end{array}$ & 0.535 & -260.00 & $\begin{array}{l}255.64 \pm \\
1912.35\end{array}$ & 0.444 & 270.00 & $\begin{array}{c}49.23 \pm \\
2100.94\end{array}$ & 0.514 & -130.00 \\
\hline Tidak & $\begin{array}{c}-499.07 \pm \\
1795.29\end{array}$ & & -400.00 & $\begin{array}{c}59.47 \pm \\
1251.71\end{array}$ & & 215.00 & $\begin{array}{c}-439.60 \pm \\
1576.49\end{array}$ & & -290.00 \\
\hline \multicolumn{10}{|c|}{ Penyakit Kardiovaskular } \\
\hline Ya & $\begin{array}{c}-431.93 \pm \\
1784.79\end{array}$ & 0.857 & -70.00 & $\begin{array}{c}460.64 \pm \\
1537.19\end{array}$ & 0.157 & 470.00 & $\begin{array}{c}28.70 \pm \\
1824.27\end{array}$ & 0.152 & 300.00 \\
\hline Tidak & $\begin{array}{c}-387.97 \pm \\
1733.98\end{array}$ & & -375.00 & $\begin{array}{c}2.50 \\
\pm 1480.11\end{array}$ & & 5.00 & $\begin{array}{c}- \\
385.47 \pm 17 \\
58.16\end{array}$ & & -365.00 \\
\hline \multicolumn{10}{|l|}{ Anemia } \\
\hline Ya & $\begin{array}{c}-423.63 \pm \\
1754.11\end{array}$ & 0.881 & -360.00 & $\begin{array}{l}82.82 \pm \\
1494.35\end{array}$ & 0.881 & 240.00 & $\begin{array}{c}-340.80 \pm \\
1671.97\end{array}$ & 0.958 & -210.00 \\
\hline Tidak & $\begin{array}{c}-252.50 \pm \\
1697.50\end{array}$ & & -145.00 & $\begin{array}{l}393.12 \pm \\
1576.94\end{array}$ & & -20.00 & $\begin{array}{l}140.62 \pm \\
2354.24\end{array}$ & & -480.00 \\
\hline
\end{tabular}

Semua faktor perancu pada

penelitian ini tidak memiliki hubungan yang bermakna $(p>0,05)$ terhadap angka leukosit. Pada visit 1-2 semua variabel mengalami peningkatan rerata angka leukosit namun tidak terjadi perningkatan secara signifikan. Pada visit 2-3 semuanya mengalami penurunan rerata kecuali pada variabel usia $\geq 60$ tahun, yaitu terjadi peningkatan rerata angka leukosit namun tidak signifikan. Pada visit 1-3 terjadi peningkatan rerata angka leukosit secara tidak signifikan pada variabel jenis kelamin pria, usia $<60$ tahun dan $\geq 60$ tahun, pasien dengan komorbid hipertensi dan anemia. Sedangkan penurunan rerata angka leukosit secara tidak signifikan pada visit 1-3 terjadi pada variabel jenis kelamin wanita, pasien dengan komorbid DM dan penyakit kardiovaskular

Tabel 5. Gambaran persentase limfosit dengan variabel perancu

\begin{tabular}{|c|c|c|c|c|c|c|c|c|c|}
\hline \multicolumn{10}{|c|}{ Persentasae Limfosit } \\
\hline \multirow[t]{2}{*}{ Variabel } & \multicolumn{3}{|c|}{ Visit 1 - Visit 2} & \multicolumn{3}{|c|}{ Visit $2-$ Visit 3} & \multicolumn{3}{|c|}{ Visit 1 - Visit 3} \\
\hline & $\begin{array}{l}\text { Mean } \pm \\
\text { SD }\end{array}$ & $p$-value & Median & $\begin{array}{l}\text { Mean } \pm \\
\text { SD }\end{array}$ & p-value & Median & Mean $\pm S D$ & $p$-value & Median \\
\hline \multicolumn{10}{|c|}{ Jenis Kelamin } \\
\hline Pria & $-0.23 \pm 4.92$ & 0.314 & 0.00 & $\begin{array}{c}0.72 \pm \\
4.97\end{array}$ & 0.475 & 0.00 & $\begin{array}{c}0.48 \pm \\
5.67\end{array}$ & 0.397 & 0.00 \\
\hline Wanita & $0.20 \pm 4.90$ & & 1.00 & $\begin{array}{c}0.53 \pm \\
3.73\end{array}$ & & 0.00 & $\begin{array}{c}0.74 \pm \\
5.22\end{array}$ & & 1.00 \\
\hline
\end{tabular}


ISSN 1978-2071 (Print); ISSN 2580-5967 (Online) Jurnal IImiah Kedokteran Wijaya Kusuma 10(1): 27- 44, Maret 2021

\begin{tabular}{|c|c|c|c|c|c|c|c|c|c|}
\hline \multicolumn{10}{|c|}{ Persentasae Limfosit } \\
\hline \multirow[t]{2}{*}{ Variabel } & \multicolumn{3}{|c|}{ Visit 1 - Visit 2} & \multicolumn{3}{|c|}{ Visit 2 - Visit 3} & \multicolumn{3}{|c|}{ Visit 1 - Visit 3} \\
\hline & $\begin{array}{l}\text { Mean } \pm \\
\text { SD }\end{array}$ & $p$-value & Median & $\begin{array}{l}\text { Mean } \pm \\
\text { SD }\end{array}$ & $p$-value & Median & Mean $\pm S D$ & $p$-value & Median \\
\hline \multicolumn{10}{|l|}{ Usia (Tahun) } \\
\hline$<60$ tahun & $0.51 \pm 4.16$ & 0.064 & 1.00 & $\begin{array}{c}0.96 \pm \\
4.47\end{array}$ & 0.615 & 0.00 & $\begin{array}{c}1.47 \pm \\
5.06\end{array}$ & 0.004 & 1.00 \\
\hline$\geq 60$ tahun & $\begin{array}{c}-1.51 \pm \\
6.21\end{array}$ & & -1.00 & $\begin{array}{c}-0.12 \pm \\
4.66\end{array}$ & & 0.00 & $\begin{array}{c}-1.63 \pm \\
5.93\end{array}$ & & -1.00 \\
\hline \multicolumn{10}{|l|}{ Hipertensi } \\
\hline Ya & $-0.09 \pm 5.10$ & 0.784 & 1.00 & $\begin{array}{c}0.68 \pm \\
4.64\end{array}$ & 0.757 & 0.00 & $\begin{array}{c}0.58 \pm \\
5.60\end{array}$ & 0.898 & 0.00 \\
\hline Tidak & $0.14 \pm 3.13$ & & 0.00 & $\begin{array}{c}0.42 \pm \\
3.77\end{array}$ & & 0.00 & $\begin{array}{c}0.57 \pm \\
4.68\end{array}$ & & 0.50 \\
\hline \multicolumn{10}{|c|}{ Diabetes Melitus } \\
\hline Ya & $0.07 \pm 5.02$ & 0.864 & 0.00 & $\begin{array}{c}0.05 \pm \\
4.72\end{array}$ & 0.348 & 0.00 & $\begin{array}{c}0.12 \pm \\
5.29\end{array}$ & 0.291 & -1.00 \\
\hline Tidak & $-0.14 \pm 4.87$ & & 1.00 & $\begin{array}{c}0.96 \pm \\
4.42\end{array}$ & & 0.00 & $\begin{array}{c}0.81 \pm \\
5.60\end{array}$ & & 1.00 \\
\hline \multicolumn{10}{|c|}{ Penyakit Kardiovaskular } \\
\hline Ya & $-0.12 \pm 4.50$ & 0.884 & 1.00 & $\begin{array}{c}1.12 \pm \\
4.68\end{array}$ & 0.934 & 0.00 & $\begin{array}{c}1.00 \pm \\
6.00\end{array}$ & 0.997 & 0.00 \\
\hline Tidak & $-0.04 \pm 5.06$ & & 1.00 & $\begin{array}{l}0.47 \pm \\
4.48\end{array}$ & & 0.00 & $\begin{array}{c}0.42 \pm \\
5.31\end{array}$ & & 0.00 \\
\hline \multicolumn{10}{|l|}{ Anemia } \\
\hline Ya & $-0.10 \pm 5.09$ & 0.871 & 1.00 & $\begin{array}{c}0.70 \pm \\
4.67\end{array}$ & 0.706 & 0.00 & $\begin{array}{c}0.60 \pm \\
5.74\end{array}$ & 0.881 & 0.00 \\
\hline Tidak & $0.12 \pm 3.63$ & & 1.00 & $\begin{array}{c}0.31 \pm \\
3.64\end{array}$ & & 0.00 & $\begin{array}{c}0.43 \pm \\
3.65\end{array}$ & & -0.50 \\
\hline
\end{tabular}

Dalam hubungan faktor perancu dengan persentase limfosit didapati ada hubungan bermakna $(p<0,05)$ pada satu faktor perancu. Pada kelompok usia $<60$ tahun didapati hubungan bermakna yaitu nilai $p$-value $=0.004$ pada visit $1-3$. Pada visit 1-2 sebagian besar variabel yang mengalami peningkatan rerata persentase limfosit namun tidak signifikan adalah jenis kelamin pria, usia $\geq 60$ tahun, komorbid hipertensi, penyakit kardiovasular dan anemia. Pada visit 2-3 semuanya mengalami penurunan rerata kecuali pada variabel usia $\geq 60$ tahun, yaitu terjadi peningkatan rerata persentase limfosit namun tidak signifikan. Pada visit 13 semuanya mengalami penurunan rerata kecuali pada variabel usia $\geq 60$ tahun, yaitu terjadi peningkatan rerata persentase limfosit namun tidak signifikan. 
Perbedaan Kadar Leukosit dan Limfosit Paska Pemberian Kombinasi Vitamin B Parenteral...

Rizaldy Taslim Pinzon, Ester Novitasari, Nining Sri Wuryaningsih

Tabel 6. Gambaran konsentrasi absolut limfosit dengan variabel perancu

\begin{tabular}{|c|c|c|c|c|c|c|c|c|c|}
\hline \multicolumn{10}{|c|}{ Konsentrasi Absolut Limfosit } \\
\hline \multirow[t]{2}{*}{ Variabel } & \multicolumn{3}{|c|}{ Visit 1 - Visit 2} & \multicolumn{3}{|c|}{ Visit 2-Visit 3} & \multicolumn{3}{|c|}{ Visit 1 - Visit 3} \\
\hline & $\begin{array}{l}\text { Mean } \pm \\
\text { SD }\end{array}$ & $p$-value & Median & $\begin{array}{l}\text { Mean } \pm \\
\text { SD }\end{array}$ & $p$-value & Median & $\begin{array}{l}\text { Mean } \pm \\
\text { SD }\end{array}$ & $p$-value & Median \\
\hline \multicolumn{10}{|l|}{ Jenis Kelamin } \\
\hline Pria & $\begin{array}{c}-89.11 \pm \\
343.82\end{array}$ & 0.260 & -91.15 & $\begin{array}{l}22.09 \pm \\
343.61\end{array}$ & 0.737 & 45.70 & $\begin{array}{c}-67.02 \pm \\
384.56\end{array}$ & 0.044 & -79.00 \\
\hline Wanita & $\begin{array}{c}-53.21 \pm \\
436.10\end{array}$ & & -44.20 & $\begin{array}{l}81.56 \pm \\
326.70\end{array}$ & & 16.80 & $\begin{array}{l}28.34 \pm \\
383.08\end{array}$ & & 71.40 \\
\hline \multicolumn{10}{|l|}{ Usia (Tahun) } \\
\hline$<60$ tahun & $\begin{array}{l}-86.35 \pm \\
395.60\end{array}$ & 0.990 & -69.75 & $\begin{array}{l}83.10 \pm \\
335.68\end{array}$ & 0.055 & 51.50 & $\begin{array}{l}-3.25 \pm \\
401.24\end{array}$ & 0.136 & 6.20 \\
\hline$\geq 60$ tahun & $\begin{array}{c}-49.20 \pm \\
340.34\end{array}$ & & 4.30 & $\begin{array}{c}-52.01 \pm \\
326.15\end{array}$ & & -3.00 & $\begin{array}{c}-101.21 \pm \\
337.37\end{array}$ & & -102.80 \\
\hline \multicolumn{10}{|l|}{ Hipertensi } \\
\hline Ya & $\begin{array}{c}-89.13 \pm \\
392.73\end{array}$ & 0.342 & -55.80 & $\begin{array}{c}48.65 \pm \\
350.93\end{array}$ & 0.402 & 50.80 & $\begin{array}{c}-40.48 \pm \\
391.37\end{array}$ & 0.521 & -17.30 \\
\hline Tidak & $\begin{array}{l}21.30 \pm \\
254.44\end{array}$ & & 36.25 & $\begin{array}{l}13.13 \pm \\
220.17\end{array}$ & & 13.20 & $\begin{array}{l}34.43 \pm \\
342.20\end{array}$ & & -21.60 \\
\hline \multicolumn{10}{|c|}{ Diabetes Melitus } \\
\hline $\mathrm{Ya}$ & $\begin{array}{c}-24.11 \pm \\
411.23\end{array}$ & 0.240 & -24.70 & $\begin{array}{c}8.79 \pm \\
344.91\end{array}$ & 0.732 & 47.90 & $\begin{array}{c}-15.31 \pm \\
375.52\end{array}$ & 0.799 & 27.20 \\
\hline Tidak & $\begin{array}{c}-102.16 \pm \\
362.07\end{array}$ & & -82.95 & $\begin{array}{l}62.56 \pm \\
333.98\end{array}$ & & 34.50 & $\begin{array}{c}-39.59 \pm \\
392.17\end{array}$ & & -24.10 \\
\hline \multicolumn{10}{|c|}{ Penyakit Kardiovaskular } \\
\hline Ya & $\begin{array}{c}-74.24 \pm \\
303.00\end{array}$ & 0.791 & -62.60 & $\begin{array}{c}99.70 \pm \\
291.28\end{array}$ & 0.249 & 60.20 & $\begin{array}{l}25.46 \pm \\
349.30\end{array}$ & 0.575 & 0.60 \\
\hline Tidak & $\begin{array}{c}-76.22 \pm \\
405.70\end{array}$ & & -32.75 & $\begin{array}{c}23.89 \pm \\
352.02\end{array}$ & & 13.95 & $\begin{array}{c}-52.33 \pm \\
397.45\end{array}$ & & -46.90 \\
\hline \multicolumn{10}{|l|}{ Anemia } \\
\hline $\mathrm{Ya}$ & $\begin{array}{c}-79.50 \pm \\
363.81\end{array}$ & 0.583 & -47.60 & $\begin{array}{c}47.12 \pm \\
340.12\end{array}$ & 0.502 & 47.90 & $\begin{array}{c}-32.37 \pm \\
395.40\end{array}$ & 0.910 & -17.30 \\
\hline Tidak & $\begin{array}{c}-52.13 \pm \\
478.50\end{array}$ & & -45.50 & $\begin{array}{l}27.03 \pm \\
328.48\end{array}$ & & -18.30 & $\begin{array}{c}-25.10 \pm \\
325.20\end{array}$ & & -69.60 \\
\hline
\end{tabular}

Sebagian besar faktor perancu pada penelitian tidak memiliki hubungan bermakna $(p>0,05)$, hanya satu variabel yang didapati memiliki hubungan bermakna dengan nilai konsentrasi absolut limfosit. Pada visit 1-3 didapati hubungan bermakna terdapat pada variabel jenis kelamin pria, yang menunjukkan perubahan rerata konsentrasi absolut limfosit secara bermakna. Pada visit 1-2 rerata nilai konsentrasi absolut limfosit pada semua variabel perancu mengalami peningkatan namun tidak signifikan. Pada visit 2-3 terjadi penurunan rerata nilai konsentrasi absolut limfosit pada semua variabel perancu kecuali pada kelompok usia $\geq 60$ tahun. Dan pada visit 1-3 terjadi peningkatan rerata nilai konsentrasi absolut limfosit pada semua variabel perancu kecuali pada pasien dengan komorbid kardiovaskular. 
ISSN 1978-2071 (Print); ISSN 2580-5967 (Online) Jurnal IImiah Kedokteran Wijaya Kusuma 10(1): 27- 44, Maret 2021

\section{PEMBAHASAN}

Pada penelitian ini distribusi responden berdasarkan jenis kelamin, dapat dilihat responden pria sebanyak 72 orang dan wanita sebanyak 43 orang. Hal ini menunjukkan bahwa responden pria lebih banyak daripada subjek wanita. Penurunan fungsi ginjal terjadi lebih cepat pada pria dibanding wanita karena adanya efek protektif pada hormon estrogen dan adanya efek perusak pada testosteron serta perbedaan dari gaya hidup yang tidak sehat (Carrero et al, 2018). Pengaruh lain dari hormon sex adalah testosteron juga menginduksi sistem renin-angiotensin dan dihambat oleh estrogen, estrogen juga berperan dalam mengurangi stress oksidatif pada ginjal dengan mensupresi aktivitas NADPH oksidase (Carrero et al, 2018).

Rerata usia subjek pada penelitian ini adalah $51,58+12,51$ tahun. Hal ini serupa dengan penelitian yang dilakukan oleh Cruz et al (2011) bahwa rerata usia pasien yang menjalani hemodialisis adalah $52,5 \pm 15,9$ tahun. Pada penelitian ini didapatkan sebanyak 82 orang berusia $<60$ tahun dan 33 orang berusia $\geq 60$ tahun. Hal ini menunjukkan bahwa 33 subjek dalam penelitian ini merupakan lansia. Fungsi ginjal menurun dengan adanya penuaan. Banyaknya penurunan LFG terkait usia berbeda antar etnik (Iseki, 2008). Pada populasi umum, usia yang lebih tua berhubungan dengan penurunan LFG dan memiliki prevalensi yang lebih tinggi mengalami albuminuria, gangguan kardiovaskular, hipertensi, diabetes, dan faktor resiko gangguan ginjal lainnya (Hallan et al, 2012).

Penelitian terdahulu menunjukkan bahwa wanita memiliki tekanan sistolik 10 $\mathrm{mmHg}$ lebih rendah dibanding pria. Tekanan darah diketahui merupakan salah satu penentu utama terbentuknya aterosklerosis dan berkembangnya penyakit ginjal tahap akhir, sehingga perbedaan tekanan darah sistolik pada masing-masing jenis kelamin mungkin berkontribusi dalam memperlambat penurunan LFG pada wanita (Chang et al, 2016).

Angka Leukosit Normal orang dewasa muda adalah $4500-11000 / \mathrm{mm}^{3}$. Data dari penelitian ini menunjukkan bahwa angka leukosit sampel penelitian pada visit 1, 2, dan 3 berada pada nilai normal. Rerata angka leukosit pada visit 1 adalah sebesar $7096.00 \pm 2244.15 / \mathrm{mm}^{3}$, visit 2 sebesar $7495.82 \pm 2369.15 / \mathrm{mm}^{3}$, dan visit 3 adalah sebesar $7369.82 \pm 2108.68 / \mathrm{mm}^{3}$. Peningkatan angka leukosit terjadi pada visit 1 ke visit 2 dan visit 1 ke visit 3, sedangkan penurunan terjadi pada visit 2 ke visit ke 3 .

Berdasarkan uji statistik pada seluruh responden dalam penelitian ini, didapatkan 
Perbedaan Kadar Leukosit dan Limfosit Paska Pemberian Kombinasi Vitamin B Parenteral... Rizaldy Taslim Pinzon, Ester Novitasari, Nining Sri Wuryaningsih

perubahan yaitu berupa peningkatan rerata angka leukosit setelah pemberian intervensi vitamin $B_{1}, B_{6}, B_{12}$ pada visit 1-2 secara signifikan dengan nilai $p$-value $=0,033$. Hal ini menunjukkan pemberian vitamin $B_{1}, B_{6}$, $\mathrm{B}_{12}$ pada visit 1-2 berperan dalam peningkatan rerata angka leukosit. Sedangkan pada visit 2-3 dan visit 1-3, tidak didapatkan perubahan rerata angka leukosit secara signifikan ( $p$-value>0,05).

Pasien dengan terapi pengganti ginjal pada umumnya sering mengalami penurunan kadar vitamin yang dapat mempengaruhi angka sel darah putih. Penurunan vitamin dapat terjadi akibat asupan diet yang tidak adekuat, penurunan absorbsi gastrointestinal, metabolisme ginjal abnormal, dan hilangnya vitamin saat dialisis. Defisiensi vitamin utamanya terjadi pada vitamin larut air yang didalamnya termasuk vitamin $B_{1}, B_{6}, B_{12}$. Penurunan nafsu makan terkait asupan diet terjadi akibat kadar leptin plasma yang tinggi serta adanya inflamasi yang menyebabkan produksi sitokin anoreksigenik (Elia et al, 2013).

Pemberian vitamin $B_{1}, B_{6}$ dan $B_{12}$ pada penelitian ini dapat dilihat telah meningkatkan angka limfosit responden terutama pada visit ke-3 yaitu setelah satu bulan pemberian vitamin. Vitamin $B_{6}$ bermanfaat dan berperan sebagai prekusor glutathion menjadi antioksidan terutama pada pasien penyakit ginjal kronik. Pada pasien penyakit ginjal kronik, keadaan uremia juga berperan pada penurunan asupan makanan. Hal ini menyebabkan kemungkinan terjadinya defisiensi vitamin, sehingga perlu diberi suplementasi vitamin termasuk vitamin $\mathrm{B}_{1}, \mathrm{~B}_{6}$ dan $\mathrm{B}_{12}$. (Elia et al, 2013)

Pasien dengan penyakit ginjal kronik pada umumnya terjadi penurunan imunitas dibandingkan dengan orang yang normal. Limfosit adalah salah satu jenis dari leukosit yang berfungsi sebagai sistem imun. Terdapat dua jenis limfosit yaitu limfosit sel T dan limfosit sel B. Sel B berperan dalam imunitas humoral dan sel $\mathrm{T}$ berperan dalam imunitas selular (Abbbas et al, 2016). Limfosit merupakan jenis sel darah putih terbanyak setelah netrofil. Persentase limfosit normal adalah $20 \%-40 \%$. Hasil penelitian ini menunjukkan bahwa rerata persentase limfosit pasien penyakit ginjal pada visit 1 (19,06\%), visit $2(19,13 \%)$, dan visit $3(18,48 \%)$ berada di bawah nilai normal persentase limfosit.

Rerata persentase limfosit pada visit 1-2 terjadi sedikit kenaikan rerata yaitu $0,7 \%$, namun terjadi penurunan pada visit 1 3. Total penurunan persentase dari visit 1 $(19,06 \%)$ ke visit $3(18,48 \%)$ adalah sebesar $0,58 \%$. Berdasarkan hasil uji statistik tidak ditemukan perubahan persentase limfosit secara signifikan pada semua visit. Hal ini 
menunjukkan bahwa pemberian vitamin B1, B6 dan B12 belum memberikan perubahan yang signifikan terhadap persentase limfosit, yang bisa disebabkan karena pemberian vitamin B kombinasi yang terlalu singkat yaitu 4 minggu pemberian vitamin secara parenteral.

Hasil penelitian ini sesuai dengan teori yang disampaikan oleh Dalrymple dan Go bahwa pada pasien ESRD terjadi gangguan pada fungsi limfosit sehingga akan mengalami defisit persentase limfosit yang akan berpengaruh terhadap daya tahan tubuh (Dalrymple dan Go, 2008). Hal ini juga sesuai dengan penelitian sebelumnya yang menyebutkan bahwa pada pasien penyakit ginjal kronik ditemukan jumlah netrofil, limfosit B dan T yang rendah serta proses hemodialis dapat meningkatkan apoptosis limfosit B dan T (Saad et al, 2014).

Pada penelitian sebelumnya yang dilakukan oleh Atziza (2015) mengenai perbedaan rerata kadar limfosit pre dan post hemodialisis, didapatkan hasil rerata kadar limfosit pre hemodialis yaitu $1969 \pm$ 729,11 dan post hemodialisis sebesar 1397 $\pm 545,23$, hal ini menunjukkan bahwa terdapat penurunan nilai kadar limfosit responden setelah dilakukan hemodialisis (Atziza et al, 2017). Hal ini dapat terjadi karena darah yang berkontak dengan permukaan membran dialiser selama proses hemodialisis menghasilkan suatu respon kompleks yang menyebabkan defek pada membran limfosit dan menurunnya masa hidup sel limfosit dalam tubuh sehingga berhubungan dengan penurunan sistem imun. Selain itu penurunan respons imun disebabkan karena terjadinya penekanan cell mediated immunity yang disebabkan oleh memendeknya umur limfosit, limfopenia, hambatan pada transformasi limfosit, dan penekanan aktivitas limfosit $T$ yang berujung pada perubahan jumlah dan fungsi limfosit (Lisoswka et al, 2016; Donati et al, 2002).

Konsentrasi absolut limfosit memiliki interval rujukan $1,0-4,8\left(\times 10^{9} / \mathrm{L}\right.$ darah $)$ pada orang dewasa. Secara keseluruhan hasil memiliki nilai normal atau berada dalam interval rujukan. Rerata nilai konsentrasi absolut limfosit mengalami peningkatan dari visit 1 (1286,33 $\pm 462,49 \times 10^{9} / \mathrm{L}$ darah) ke visit $2\left(1362,02 \pm 594,45 \times 10^{9} / \mathrm{L}\right.$ darah), sedikit penurunan dari visit 2 ke visit 3 $\left(1362,02 \pm 594,45 \times 10^{9} / \mathrm{L}\right.$ darah), serta peningkatan dari visit $1(1286,33 \pm 462,49$ 0 $/ \mathrm{L}$ darah) ke visit $3(1317,69 \pm 580,49$ $\mathrm{x} 10^{9} / \mathrm{L}$ darah). Namun berdasarkan uji statistik, pemberian vitamin $B_{1}, B_{6}$, dan $B_{12}$ tidak berpengaruh secara signifikan ( $p$ value $>0,05$ ) terhadap perubahan rerata konsentrasi asbolut limfosit pada semua visit. Hasil akhir menunjukkan terjadi peningkatan konsentrasi absolut limfosit 
Perbedaan Kadar Leukosit dan Limfosit Paska Pemberian Kombinasi Vitamin B Parenteral... Rizaldy Taslim Pinzon, Ester Novitasari, Nining Sri Wuryaningsih

ditandai dari lebih tingginya angka pada visit ke 3 yaitu 1317,69 (x10\% /L darah) dibanding visit 1 yaitu 1286,33 (x10\% / darah). Total peningkatan konsentrasi absolut limfosit adalah sebesar 31,36 (x109/L darah).

Vitamin B6 memiliki peran penting dalam pertahanan antioksidan melalui pembentukan sistein yang merupakan prekusor dari sintesis glutathion. Glutathion memiliki peran dalam proliferasi limfosit dan sistem pertahanan antioksidan. Peningkatan produksi oksidan dapat menyebabkan kerusakan jaringan sehat pada tubuh. Defisiensi vitamin $B_{6}$ dapat menyebabkan gangguan pada jaringan limfoid, penurunan limfosit pada nodus limfatikus serta limpa, serta penurunan angka limfosit total.

Vitamin B6 juga dibutuhkan secara kritis untuk penyerapan vitamin $B_{12}$ dan sintesis niasin. Selain itu, dapat menghambat trombosit agregasi, dan memperbaiki perkembangan neuropati diabetik (Metz et al, 2003; Kobzar et al, 2009). Sebaliknya, defisiensi vitamin $B_{6}$ merusak pematangan limfosit, pertumbuhan dan proliferasi, dan produksi antibodi yang akan menekan produksi Th1 dan sitokin, dengan demikian, mempromosikan respon dari Th2 (Maggini et al, 2007).
Penelitian sebelumnya menunjukkan manfaat suplementasi folat $(5 \mathrm{mg})$ dan vitamin $B_{6}(250 \mathrm{mg})$ juga mengakibatkan penurunan konsentrasi homocysteine, perbaikan profil lipid dan gejala polineuropati perifer serta mengurangi pembentukan kalsium oksalat pada pasien yang dirawat dengan hemodialisis (Ziakka et al, 2001). Pemberian dosis vitamin $B_{6} 50$ hingga $100 \mathrm{mg} /$ hari dapat menjadi nilai terapeutik yang hebat pada pasien hemodialisis.

Dalam sistem imun, vitamin B12 berfungsi dalam meregulasi sistem imun, sebagai imunomodulator dalam imunitas seluler serta terlibat dalam pembelahan sel. Penelitian menunjukkan bahwa defisiensi vitamin B12 menyebabkan penurunan signifikan jumlah sel T sitotoksik dan sel natural killer (NK) (Mikkelsen et al, 2017). Pemberian vitamin B12 pada pasien dengan defisiensi vitamin B12 memfasilitasi produksi limfosit $T$, imuntas seluler dan mempertahankan jumlah subkelompok limfosit dalam kisaran normal (Lewicki et al, 2014).

Kerusakan genom dalam limfosit darah tepi pasien dialisis disebabkan karena stres oksidatif. Stres dapat diperbaiki dengan suplementasi asam folat dan vitamin $B_{12}$ yang diperkirakan berkontribusi terhadap pengurangan homocystine (Stopper et al, 2008). Infeksi, stres oksidatif, 
ISSN 1978-2071 (Print); ISSN 2580-5967 (Online) Jurnal Ilmiah Kedokteran Wijaya Kusuma 10(1): 27- 44, Maret 2021

dan peradangan telah terbukti mengurangi responsif terhadap agen perangsang erythropoiesis dengan meningkatkan pelepasan proinflamasi sitokin. Stres oksidatif dan peradangan bisa terjadi dilemahkan oleh vitamin B12 dan suplementasi asam folat (Stenvinkel, 2003).

Pada penelitian ini dilakukan juga pengujian data statistik antara angka leukosit, perentase limfosit dan konsentrasi absolut limfosit dengan variabel perancu. Sebagian besar didapatkan hasil yang tidak signifikan yaitu $p$-value $>0,05$. Pada pengujian data konsentrasi absolut limfosit di visit 1-3 berdasarkan jenis kelamin didapatkan hasil yang signifikan dengan nilai $p$-value $=0.044$. Pada pengujian data persentasae limfosit di visit 1-3 terdapat hasil yang signifikan pada kategori usia dengan $p$-value $=0.004$.

Penurunan fungsi ginjal dalam skala kecil merupakan proses normal seiring bertambahnya usia tetapi tidak menyebabkan kelainan jika masih dalam batas yang normal dan dapat ditoleransi oleh ginjal dan tubuh. Salah satu faktor penurunan fungsi ginjal adalah usia, karena dengan bertambahnya usia maka semakin berkurang fungsi ginjal dan juga berhubungan dengan penurunan kecepatan ekskresi glomeruli serta memburuknya fungsi tubuli ginjal. Kemampuan sistem imun pada kelompok lanjut usia akan semakin menurun sesuai peningkatan usia, termasuk dalam hal kecepatan respons imun melawan infeksi penyakit ginjal kronik ini, dikarenakan pada lansia produksi imunoglobulin juga akan menurun (Hasdinah et al, 2014).

\section{KETERBATASAN PENELITIAN}

Penelitian ini dilakukan dengan durasi yang singkat yaitu selama 4 minggu dan pemberian kombinasi vitamin B hanya diberikan $2 x$ dalam seminggu setiap kali hemodialisis oleh sebab itu perubahan berupa peningkatan rerata angka leukosit, persentase limfosit dan konsentrasi absolut limfosit setelah pemberian vitamin $B_{1}, B_{6}$, dan $B_{12}$ belum terjadi secara signifikan. Penelitian ini juga tidak memiliki kelompok kontrol perlakuan (tidak diberikan vitamin).

\section{KESIMPULAN}

Pemberian vitamin $B_{1}, B_{6}$, dan $B_{12}$ dalam penelitian ini terbukti aman. Tidak ditemukan adanya efek samping pemberian obat pada seluruh subjek penelitian. Terdapat perbedaan berupa peningkatan rerata angka leukosit secara bermakna pada visit $1-2$ dengan $p$-value $=0.033$ setelah pemberian $B_{1}, B_{6}$, dan $B_{12}$. Tidak ada perbedaan yang bermakna setelah pemberian vitamin $B_{1}, B_{6}, B_{12}$ terhadap rerata persentase limfosit dan konsentrasi absolut limfosit. Pemberian vitamin B1, B6, dan B12 berdasarkan hasil penelitian ini 
Perbedaan Kadar Leukosit dan Limfosit Paska Pemberian Kombinasi Vitamin B Parenteral... Rizaldy Taslim Pinzon, Ester Novitasari, Nining Sri Wuryaningsih

masih belum cukup untuk menjadi masukan sebagai terapi pada pasien penyakit ginjal kronik yang menjalani hemodialisis, sehingga dibutuhkan penelitian lebih lanjut dengan jumlah sampel yang lebih besar untuk mempertimbangkan pemberian vitamin B kombinasi sebagai terapi tambahan pada pasien penyakit ginjal kronik.

\section{DAFTAR PUSTAKA}

Abbas A, Lichtman A, Pillai S, 2016. Imunologi Dasar Abbas: Fungsi dan Kelainan Sistem Imun. 5th ed. Elsevier, Singapore.

Atziza R, Ayu P, Yonata A, 2017. Perbedaan Kadar Limfosit Pre dan Post Hemodialisis Pasien Gagal Ginjal Kronik. Medula. 7(4): 37-41.

Bikbov B, Purcell CA, Levey AS, Smith M, Abdoli A, Abebe M, et al. 2020. Global, Regional, and National Burden of Chronic Kidney Disease, 1990-2017: A Systematic Analysis for The Global Burden of Disease Study 2017. The Lancet. 395: 709733.

Carrero J, Hecking M, Chesnaye N, Jager K, 2018. Sex and Gender Disparities in The Epidemiology and Outcomes of Chronic Kidney Disease. Nature Reviews Nephrology. 14(3): 151-164.
Chang P, Chien L, Lin Y, Wu M, Chiu W, Chiou H, 2016. Risk Factors of Gender for Renal Progression in Patients with Early Chronic Kidney Disease. Medicine. 95(30): e4203.

Dalrymple L, Go A, 2008. Epidemiology of Acute Infections Among Patients With Chronic Kidney Disease. Clinical Journal of the American Society of Nephrology. 3(5):14871493.

Elia $M$, Ljungqvist $\mathrm{O}$, Stratton $\mathrm{R}$, LanhamNew S, 2013. Clinical nutrition. 2nd ed. Wiley-Blackwell, John Wiley \& Sons, Oxford.

Hallan S, Matsushita K, Sang Y, Mahmoodi B, Black C, Ishani A, et al, 2012. Chronic Kidney Disease Prognosis. Age and Association of Kidney Measures with Mortality and Endstage Renal Disease. JAMA. 308(22): .2349.

Hasdinah HR, Dewi P, Peristiowati Y, Imam S, 2014. Imunologi - Diagnosis dan Teknik Biologi Molekuler. Nuha Medika, Yogyakarta.

Iseki K, 2008. Gender differences in chronic kidney disease. Kidney International, 74(4): 415-417.

Kobzar G, Mardla V, Rätsep I, Samel N, 2009. Effect of vitamin $B(6)$ vitamers on platelet aggregation. Platelets. 20(2): 120-124. 
Lewicki S, Lewicka A, Kalicki B, Kłos A, Bertrandt J, Zdanowski R. 2014. Experimental Immunology The Influence of Vitamin B 12 Supplementation on The Level of White Blood Cells and Lymphocytes Phenotype in Rats Fed a Low-Protein Diet. Central European Journal of Immunology. 419-425.

Lisowska K, Dębska-Ślizień A, Jasiulewicz A, Bryl E, Witkowski J, 2013. Influence of Hemodialysis on Circulating CD4lowCD25 high Regulatory T Cells in End-Stage Renal Disease Patients. Inflammation Research. 63(2): 99-103.

Maggini S, Wintergerst ES, Beveridge S, Hornig DH, 2007. Selected Vitamins and Trace Elements Support Immune Function by Strengthening Epithelial Barriers and Cellular and Humoral Immune Responses. British Journal of Nutrition. 98(S1): S29-S35.

Metz T, Alderson N, Thorpe S, Baynes J, 2003. Pyridoxamine, an Inhibitor of Advanced Glycation and Lipoxidation Reactions: A Novel Therapy for Treatment of Diabetic Complications. Archives of Biochemistry and Biophysics. 419(1): 41-49.
Mikkelsen K, Stojanovska L, Prakash M, Apostolopoulos V, 2017. The Effects of Vitamin $B$ on The Immune/Cytokine Network and Their Involvement in Depression. Maturitas. 96:58-71.

Saad K, Elsayh K, Zahran A, Sobhy K, 2014. Lymphocyte Populations and Apoptosis of Peripheral Blood B and $\mathrm{T}$ Lymphocytes in Children With End Stage Renal Disease. Renal Failure. 36(4): 502-507.

Stenvinkel P, 2003. Anaemia and Inflammation: Ahat are The Implications for The Nephrologist. Nephrology Dialysis Transplantation.

Stopper H, Treutlein AT, Bahner U, Schupp N, Schmid U, Brink A, et al, 2008. Reduction of The Genomic Damage Level in Haemodialysis Patients by Folic Acid and Vitamin B12 Supplementation. Nephrology Dialysis Transplantation. 23(10): 3272-3279.

Suwitra K, 2014. Penyakit Ginjal Kronik. In: S. Setiati, I. Alwi, A. Sudoyo, M. Simadibrata, B. Setiyohadi and A. Syam, ed., Buku Ajar Ilmu Penyakit Dalam Jilid II, 6th ed. Jakarta: InternaPublishing, pp.2161-2167.

Wilson C, Vergara-Lluri M, Brynes R, 2017. Evaluation of Anemia, Leukopenia, 
Perbedaan Kadar Leukosit dan Limfosit Paska Pemberian Kombinasi Vitamin B Parenteral... Rizaldy Taslim Pinzon, Ester Novitasari, Nining Sri Wuryaningsih

and Thrombocytopenia. In: E. Jaffe, D. Arber, E. Campo, N. Harris and a. Quintanilla-Martinez, ed., Hematopathology, 2nd ed. Elsevier, Philadelphia. 195-234.

Ziakka S, Rammos G, Kountouris S, Doulgerakis C, Karakasis $P$, Kourvelou C, et al, 2001. The Effect

of Vitamin B6 and Folate
Supplements on Plasma

Homocysteine and Serum Lipids Levels in Patients on Regular Hemodialysis. International Urology and Nephrology. 33(3): 559-562. 